\title{
De-scaling without Democratic Substance
}

Water Provisioning in Peripheral Kano, Nigeria

\section{Gunilla Andrae}

\section{(2) OpenEdition}

\section{Journals}

Édition électronique

URL : http://journals.openedition.org/apad/4051

DOI : 10.4000/apad.4051

ISSN : 1950-6929

Éditeur

LIT Verlag

\section{Édition imprimée}

Date de publication : 1 décembre 2010

ISBN : 978-3-643-10535-6

\section{Référence électronique}

Gunilla Andrae, "De-scaling without Democratic Substance », Bulletin de l'APAD [En ligne], 31-32 | 2010, mis en ligne le 22 septembre 2010, consulté le 08 septembre 2020. URL : http:// journals.openedition.org/apad/4051 ; DOI : https://doi.org/10.4000/apad.4051

Ce document a été généré automatiquement le 8 septembre 2020.

Bulletin de I'APAD 


\title{
De-scaling without Democratic Substance
}

\author{
Water Provisioning in Peripheral Kano, Nigeria
}

Gunilla Andrae

\section{Introduction}

\section{Research Questions}

1 Liberalisation of water supplies in a situation of rapid urban expansion has made for great changes in water provisioning patterns in many African cities. While publicly controlled utilities with piped systems for distribution continue to serve the formal economy and the well-to-do citizens, they have increasingly been supplemented with various other modes of provision for and by the poor. Highly fragmented and largely informalised structures are playing an increasing role, not only in practice but also as a recognized and expanding form for satisfying basic needs of the urban masses. Such fragmented supply structures have made for highly dispersed forms of provisioning. Located at scale levels below the municipal and even beyond the reach of local governments, these dispersed small-scale providers commonly show new forms of regulation and new relations between providers, users and concerned citizens. In this situation, agents concerned with the process of democratisation and the introduction of a human rights perspective to the provision of basic services have put popular access and influence over matters of access high on the agenda. As a result, the issue of the nature of community level governance has come to the fore, in particular as it relates to the scope for democratic modes of popular influence in locations where state authority is weak.

2 These matters are discussed in this article using a case study of the peripheral lowincome community of Tudun Murtala in the large old city of Kano on the savannah of northern Nigeria in West Africa as the point of departure. My assumption is that for state backed democratic regulation of water provision for the poor to be realized, the 
regulatory powers of the state will need to reach beyond the local government level, which is where decentralisation policies are currently targeted. To effectively regulate the actual conditions of supply, these powers need to reach even further down, to the level of the community, where their current weakness leaves uncontested scope for alternative forces which do not necessarily cater for the interests of the low-income population. In the community studied here, legacies of colonial indirect rule remain in the form of neo-traditional modes of regulation of popular access to livelihood resources, and in a weak tradition of collective action, even on issues of provision of basic services. We may consider parliamentary democracy as the main guarantor of democratic representation in the realization of popular rights of access to water, or leave the door open for alternative 'substantial' modes of popular influence on access. Probing the place specific forms of governance at the community level, and in particular the forms of articulation between state based institutions and other forms for deliberation, will contribute necessary understanding of use in realizing democratic access to water in an era when provision of this service is increasingly fragmented and dispersed.

\section{Research Context and Data : 'People, Provisioning and Place in African Cities'}

3 The Nigerian case study reported here was carried out in the context of a series of studies of contemporary changes in urban service and livelihood in Africa at the Department of Human Geography at Stockholm University during 1998-2007. The focus of this programme, People, Provisioning and Place in African Cities ${ }^{1}$, was the implications of liberalisation and globalisation for agency of provision and regulation of basic means of livelihood in the cities. In some of the studies the changes in modes of popular influence on distribution and access to resources, under variable local conditions, have been explored. The programme contained studies of different African cities and on different sectors of livelihood and service provision, with similar analytical departures, among these are Adama (2007), Appelblad, (2008), Cadstedt (2006), Kjellén (2006). My own case study concerns patterns of water provisioning ${ }^{2}$ in one expanding peripheral low-income area in Kano. A fuller empirical account of the agents and relations of water provisioning there has been published as Andrae (2005) where fuller references to its source materials are also given. The sources include qualitative interviews with key informants in Tudun Murtala ; at Kano State Water Board ; Kano State Environment Planning and Protection Agency, KASEPPA; and Community Action for Popular Participation, CAPP, in 2000 and 2002. They also include two consultancy reports made for Kano Water Board that were the basis for external donors to fund reforms at the dysfunctional central public utility. ${ }^{3}$ I further rely on my networks from earlier studies on Kano over the past decades (Andrae \& Beckman 1985, 1998). Preliminaries to the present article were presented at conferences on Decentralisation in Practice in Uppsala $2004^{4}$ and on Human Rights Movements in Nigeria held in Kano in 2007 (Andrae 2007). The present article is a more analytical development of these empirical presentations, where the main contribution is to problematise the implications for democratic popular influence of the de-scaling of water provision in a situation where secular organisation at the community level is weak and largely pre-empted by the strength of neo-traditional powers. Renewed contacts with informants in Tudun Murtala in 2007 
confirmed that, apart from a colossal expansion of local private boreholes, the same basic provisioning model remained in place.

\section{Analytical Framework and Relation to Current Discourses}

4 Historically in African urban water provision, public utilities managed at the municipal level have a central role (Nilsson 2006). With the break-up of state monopolies into several components with different ownership, we can clearly see that there is a spatial dimension to change. Degree of dispersal and patterns of location relate to the altered structures of supply and regulation. The changes in supply structures, in forms for regulation, and in location patterns, are also reflected in changes in provisioning relations to users and citizens. These in turn will entail different conditions for democratic popular influence. The role of, and scope for, parliamentary forms for democratic regulation versus 'substantial' democracy modes depend on historic place specific factors that may fruitfully be sought through comparative case oriented research. While there may be general logics of location and of governance associated with the scale of administration and management, we can also expect to find particular scale and place specific logics, where socio-cultural and political factors operating at different levels in the spatial systems influence the outcome. Some elaboration is in order.

5 The dominating form for liberalisation of urban water supplies in Africa, that has been commonly adopted in national government policies and eagerly championed by the World Bank, has been the take-over by transnational companies of ownership or management in previously publicly owned water utilities. While this was a rather aggressive development running through the 1990s (Hall, Bayliss \& Lobina 2002 ; UNDP 2006), it seems that we may already be entering a post-privatisation era at this level of large-scale supplies. With increasing popular resistance (Hall et al. 2005), and as the costs of operating the run-down public pipe-born systems are rapidly becoming evident to the transnational companies, the thrust for privatisation on this model is increasingly giving way to re-nationalisation. One example of this is Tanzania (Kjellén 2006). We are also beginning to see various other forms for commercialisation, still under public control, as in the case of Uganda (Appelblad 2008). All along we have, however, seen another parallel and still ongoing process of establishment of small and fragmented non-public suppliers. It occurs in replacement of the breaking-down public systems of water supply (which often date back to early colonial times), and has come to constitute a major mode of provision for the needs of the masses of the urban poor in many African cities. It is a development that connects with what was for a long-time the only available form for developing supplies in the rapidly expanding peripheral and often unplanned areas of cities. Covered by Kjellén and McGranahan (2006) this smallscale and mainly informally organised privatisation of provision for the urban poor, already described by Solo (1999), has attracted continued attention in conjunction with recent movements at the international level to enforce the access to water as a human right (UN Economic and Social Council, 2003). It includes renewed concerns, mainly on the part of international agencies and donors and more rarely of national government authorities, for the need to extend public responsibilities for service provision beyond the wealthy elites to these majorities, if not by supply then at least by regulation of the relations of provision. The 2006 UNDP World Development Report dealing with water thus puts strong emphasis on the problem of governance (UNDP 2006). 
6 The modes of poor people's provisioning and the politics involved in these are attracting increased attention within the research community. Remembering that even rights-based regimes do not preclude the need for the urban poor to actively contesttheir rights of access, there are strong pressures on researchers to contribute better understandings of the modes of insertion of the poor in existing and developing provisioning regimes, and to provide knowledge that is of use for their struggles for better access. Seen as a matter of empowerment, the political dimension must not be allowed to be concealed in top-down modes of provision under the concept of participatory management.

7 The large-scale utility systems typical of the pipe-born supplies inherited from colonial times are commonly run from the metropolitan level, obeying the logics of 'natural monopolies' with potentials for large economies of scale to be gained by concentration of processing, distribution and administration (Belli 1997; Kjellén 2006 ; Nilsson 2006 : Article 3). In the peripheral areas where the metropolitan grid no longer reaches, or where it is no longer functional due to lack of maintenance, the smaller-scale providers take over as suppliers in highly fragmented structures of establishments located at the level of the neighbourhood community. With current rapid expansion in the peripheries of the cities, this type of supplier already dominates in supplying the poor populations

8 Our concern here is that in much of Africa, the state authorities have not only let go of their supply functions, legitimized by reigning neo-liberal ideologies as promoted notably by the World Bank. They have also lost their regulating functions concerning service supplies that are targeting the urban poor, as they have been allowed to develop in distant peripheries by a largely unregistered mass of providers. We can then expect to find that regulation of relations around these peripheral supply points will be in the hands of forces other than the local government, as these will take place in communities where the powers of the 'secular' state hardly reach. The result will be a kind of decentralisation of regulation 'by default', driven by the de-scaling of supplies through expansion of small-scale and informal forms of provision.

Strategies of decentralisation of service provision as a policy option have become a common component of liberalisation policies and rhetoric, and have usually been based on ideas of the democratic potentials that can be realised by moving control over basic livelihood services closer to the people. Such ideas have been championed by the global donor community in furtherance of impacts on efficiency, resource mobilisation, local relevance and popular participation (see Cheema 2005 ; Chikulo 1998 ; and for Nigeria, Crook \& Manor 1993; Gboyega 1998). The need for renewed awareness of the significance of the spatial level below that of the local government, the community level, in the decentralisation problematic concerning regulation of service provision is underlined by the community case I have chosen to study (Andrae 2005). Clearly the currently popular notions of 'Spaces for Democracy' (Barnett \& Low 2006) and 'Spaces for Change' (Cornwall and Coelho 2007) need to be applied in the literalsense of where the power game around access to services by the poor is actually played out, since this has implications for who regulates access, influence and empowerment to whose benefit. In this context it is pertinent to maintain that concern with community level governance will need to move to a more central place in this analysis.

10 The character of alternative community level regulation structures is of course variable, and the conditions of variation are matters that we need to further explore 
empirically. The definition of place specificities and variations of local patterns in the different institutional, socio-political and physical contexts are pressing challenges for geographical research, not least if the arguments are to be effective against the generalised policies and loan conditionality pushed by the powerful global finance institutions. Contributions of case studies may produce a basis for defining relevant parameters for comparative studies. This is thus one purpose of the analysis of the case presented here.

11 We apply a concept of governance that, in this context, looks as follows. ${ }^{5}$ With the rapid fragmentation of water supplies, we observe a growing number of forms of water provision with different conditions of access. Whether mediated by the market, or by public or communal supply, access will be influenced by the regulation by powers that may rest with the state, private owners collective organisations of users, or of other citizens who support their cause. These rule-setting agents are, however, only one side of the governing relation. Successful regulation rests on relations to the users, or other citizens, with political interest in the supply, and depends on their legitimisation of the arrangement of supply. The resulting structure of provisioning relations is what we term a mode of governance. Operationally we may delimit these relationships by looking for the users of the various supplies, and particularly their agency of demand-making, on the one hand, and then, on the other hand, define the authorities that enter into regulating relations, for groups of suppliers, with the demand making users (and their political allies) ${ }^{6}$. This is the approach applied in the case treated here.

There is a spatial dimension to the mode of governance. The holders of rule-setting power may relate to the concerned population from and over different scale levels. Since administrative state structures are important in regulation of services, the notions of space and scale may in this case follow these state administrative structures. From the point of view of one particular spatial level we may talk of 'multi-level governance' (Elander 2002). We may finally expect a variation in governance according to specific conditions in particular places.

13 The regulating structures that we expect in the African context are, first of all, the public authorities, which come in very different shapes. Mamdani (1996) has drawn attention to the existence of the bi-furcated state, where the colonial powers have left legacies of their neo-traditional systems of indirect rule, which in some places still remain. Lund (2006) has developed the notion of the 'twilight state' indicating the range of forms of public authority structures that may perform state-like functions. And Buur and Kyed (2006) in the above publication by Lund, have given us interesting examples of alternative agents performing such functions in the context of weak or destroyed state authority (e.g. in post-war Mocambique). The blurred nature of state authority will be particularly pertinent at the local level, where the presence of the modern states has usually been particularly weak. Policies of decentralisation of state functions have usually been aimed at addressing this structural phenomenon, while usually considering the local government level low enough for reaching the whole population.

14 A specific condition in the case of Northern Nigeria in general, and Kano in particular, is then the strength of its heritage of neo-traditional rule, once the very model for British colonial indirect rule, and the viability of its remnants. The implications of this for the mode of governance and the potentials for popular influence over water 
provisioning gives the chosen case its very specific character, well suited for demonstrating the significance of local conditions for the relations of service provision.

When it comes to popular influence over access and conditions of access, it is clear that the clientilistic relations between neo-traditional authorities and community residents are not favourable for collective organising. In other situations where the conditions for civic organising have been strong, as in South Africa, they have been shown to hold potentials for channelling real influence, as demonstrated by Stokke and Oldfield (2002). The experience is that where these are restricted or historically weak, the 'space' for alternative modes of 'substantial' democratic influences is considerably narrowed (see Gaventa 2004 and also Harriss et al. 2004, where the contribution by Törnquist is of particular relevance). This puts great weight on the functioning of parliamentary modes of representation of popular interests, and on the structure of the state institutions for fair regulation of the provision of a basic needs service, such as water. Alternatively the recent search for functioning modes of 'deliberative democracy' à la Habermas and 'new forms of citizenship' must continue (as discussed by Gaventa 2007, who rather uses the term 'substantive democracy').

Departing from the observation of the recently de-scaled location of water supply to the low-income community of Tudun Murtala, we have thus set out to probe the spatial structure of the relations of regulation over water as seen from the perspective of this community. We note that these relations result in a spatially skewed governance structure, where the regulation of supplies has to a very high degree come to be played out at the community level. The question in focus, then, concerns the implications that this structure of relations will have for the democratic influence that users and citizens may exert on their access to household water.

\section{The Case of Tudun Murtala, Kano}

\section{Research Area}

17 The area of our case study, Tudun Murtala, was a rapidly expanding low-income community of some 20,000 inhabitants at the time of this study, in 2000 and 2002. It is situated on the north-eastern outskirts of the city of Kano. With over two million inhabitants, this is the second city of Nigeria, located in the far north of the country. It is an industrial and administrative centre with long historical standing as a Muslim cultural and religious node in the Nigerian North and the surrounding Sudan region. It is a city within Kano State, which is one of 36 states (or provinces) in the Nigerian Federation. These are divided into local government areas, each with its own local government council. Tudun Murtala is part of Nassarawa local government area. The parallel neo-traditional authority structure contains the Emir of Kano to which a number of district-heads, appointed by him, report. The districts are divided into wards with ward heads who are popularly elected for life. At the time of my study Tudun Murtala had recently been expanded from one ward with one head to four wards, each with their own ward head. Of these, one was particularly vocal and enterprising and was one of my respondents. His information on the role of ward heads as agents in the provisioning game at this level is amply used in this case.

18 The origin of the community is as a resettlement area of people who were earlier living in the adjacent Bompai area, which was designated an industrial area half a century 
ago. The core of the population today is of Muslim Hausa origin, from Kano and its surrounding rural regions, with smaller numbers of southern immigrants that belong to a Christian religion.

\section{De-scaled Supply and Decentralised Regulation}

19 In Kano the colonial piped water utility, built in the 1930s, has been allowed by the city level public authorities to deteriorate, particularly in low-income residential areas outside the walled historic inner City and the central high-income Government Residential Areas (GRAs). In the old outer areas most of the piped public supply has, as it has gradually broken down, been replaced by a host of non-public sources of supply. Similar sources of supply are also emerging in the rapidly growing new expansion areas of these same communities. It is this process of privatisation by fragmentation and informalisation from the previously centralised city level public supply that can be shown to have resulted in a de-scaling in agency of supply down to the community level. The result is summarised in Table 1, which thus shows the situation in the community of Tudun Murtala in the first years of this century.

Table 1 : Agents involved in supply by scale level and mode of regulation

\begin{tabular}{|c|c|c|c|}
\hline Mode of regulation & Scale level of supply & & \\
\hline & Community & Local Govt. & City \\
\hline State & Water tap & Self-help Funding & Pipe grid \\
\hline State through formal market & $\begin{array}{l}\text { Tap operator } \\
\text { Bore hole }\end{array}$ & Competing industry & \\
\hline Informal market & Vendors & & \\
\hline Neo-traditional & $\begin{array}{l}\text { Mosque } \\
\text { Communal } \\
\text { Well }\end{array}$ & & Philanthropy \\
\hline Household/Self & $\begin{array}{l}\text { House wells } \\
\text { Self-help labour }\end{array}$ & & \\
\hline
\end{tabular}

Reading down the columns we see the various agents involved in supplying water that are found at different spatial levels from community through local government to city level. In the rows in the table these sources are categorized according to principles of regulation which have replaced the increasingly deficient state regulated supplies. I have termed these principles modes of regulation and they are shown to range from state to formal (state regulated) and informal market, neo-traditional and finally household/ self regulation. We will look at the supply structures and regulation structures in turn. ${ }^{8}$ The public piped water source, which previously supplied the central sections of the community of Tudun Murtala from a handful of community stand-pipes, had by the year 2002 been reduced to a single commercially operated water tap at the entrance to 
the area. Operators of commercial deep bore-holes, and independently working water vendors distributing the water from these outlets and from the only functioning local tap on the metropolitan grid, are now major providers, who have stepped in to supplement the common shallow hand-dug house wells and a few wells provided by the mosque and by the community. Together they form the core of a supply system that has thus moved from a highly centralised publicly controlled one to a highly decentralised one involving a multitude of non-state providers.

The community-based supplies are supplemented by those initiated at the city and local government levels. These involve the services of self-help groups and the 'philanthropists' of religious and political motivation. Self-help groups are a form for co-operation between community groups and the local government in the field of physical water regulation with focus on prevention of further erosion along the drainage channels. It is in this case manifested in public sponsorship and financial support for a community based group with a chairman who is locally elected through the mediation of and dependence on patronage from the neo-traditional ward heads. The motive behind this public support for water management lies primarily in the prevention of pollution of household wells. It is one of the few contact points between local government and the community regarding water supplies.

Supply by philanthropists along neo-traditional lines, e.g. by donation of water by tanks, has been a possibility that has kept local agents of negotiation alert, as it has had considerable impact in the neighbouring area of Tudun Wada. The main source of such supply is wealthy men at the city level. Similarly, gifts for political patronage have been received all the way from the national level. As an example, in the 1999 election campaign, gifts of electrical equipment of use for mechanical bore holes were received from a national politician. The possibility of supplies of such services caused local power brokers to pay attention to the relevant networks outside their community.

But the supply picture also includes external limitations on supply of water. Shortages due to intermittent periods of drought have lead to swings in ground water supplies. These have also affected the neighbouring industry, which has tended to make demands on the water of the residential community which is located further down the same main municipal pipe, thus aggravating the shortage there. It has led to the need for negotiation on behalf of the whole community, again with active mediation of the ward heads, but also of other representatives of the civil society that relate to these. Industrial pollution of the water from the natural stream running through the community, has further affected some of the neighbouring household wells. This is another concern where the community needs to negotiate as a unit with the industry.

We understand this supply structure as being the result of what we may speak of as a process of de-scaling of supply 'by default',andas a by-product of the process of privatisation which can in this case also be characterised as having occurred by default (following the breakdown of the infrastructure). Supply is de-scaled largely through the logics of location tied to the informalisation of services, and by dependence on small-scale suppliers. This mode of privatisation supplements the more programmatic policy proclaimed from the national level as a condition for World Bank loans that were offered at this time for the overhaul of the public utility and the piped supply of the more central areas of the city. Though proclaimed, they were implemented only in the form of one small pilot purification plant to serve the industry. What remains of the 
central municipal utility continues to supply central high-income residential, commercial and public administration areas.

Let us then move to looking at the regulation structures. In the social life of Tudun Murtala issues of water supply constantly require mediation and regulation between different interests. When most of the water consumed at the household level could be drawn from the supplies administrated by the Kano Water Board through the piped system, this administering authority was the target of negotiation regarding claims for better supplies. Claims could (in theory) be channelled through the parliamentary system through the locally elected local government councillors representing the wards. They were probably just as often carried forth by direct approaches to the supplier from lobbying coalitions of local representatives, as we shall see below.

The changing agency structure of supply has led to adjusted patterns of negotiation and brokerage where the pattern of location plays a part. The rows in Table 1, above, indicating the dimension of modes of regulation, enable us to summarize the complexity of the spatial dimension of the combined supply and regulation structure. It helps us to see how large sections of community level supplies have come to be controlled by the informal market regulators, traditional authorities and by households, who to a large extent lead their lives outside the formal economy.

Apart from privatisation of small-scale supplies, by design and by default, the other main process in the provisioning game in the recent times of liberalisation is the separation of regulation from supplies. Even when the supply function gets devolved to levels nearer to the users, this leaves a measure of regulating functions still in the hands of the state, but largely devolved to lower scale levels. Public regulation and management have in this process been largely devolved to the local government level in the form of certain control functions. Licensing of the new and rapidly expanding commercial and privately owned deep 'mechanical' wells is thus done by the local government, and is followed by intermittent inspections of water quality by the same agent. In addition there are said to be occasional checks of the common household wells, particularly when there are outbreaks of cholera, as in 2001. Public regulation by the local government ends there, however.

The essence of this development is that with the de-scaling of supplies, other regulating functions have taken hold of the community level supplies, which implies that these have, to the same extent, escaped from the reach of the local government. Here the situation in Kano has its own characteristics. The colonial heritage of indirect rule that existed there up to Independence in 1960 has resulted in a division of labour with neo-traditional authorities still in control of basic livelihood conditions at the community level, particularly in low income areas. As reported by Gboyega (1998), a series of reforms for the dismantling of indirect rule have since sought to limit the formal powers of the neo-traditional office bearers to the mediation of 'peace and harmony' in the spheres of community - household relations. Some very basic functions have, however, remained in the hands of the neo-traditional ward heads. In Tudun Murtala, for instance, they still took care of the registration of land transfers according to officials at the Kano state planning authority, KASEPPA (interview 2002). The recent process of small-scale development and informalisation of service provision in the case of water has the result of pushing this balance of regulation even further in favour of neo-traditional authorities at the community level. This becomes visible when 
we look at the ways local users and citizens articulate their demands for access and influence over access to water, and to whom their demands are directed.

My study of the patterns of demand-making over issues of access to water in Tudun Murtala shows that it is when it comes to conflicts between community based commercial providers, such as formal deep-well managers and informal vendors, on the one hand, and the water-using residents of the community, on the other, that the capacity and the legitimacy of neo-traditional authorities to handle the regulation of these conflicts become visible. ${ }^{9}$ The ward heads play a part in mediating between agents of supply, internal and external to the community, and their authority is difficult to circumvent for community residents. ${ }^{10}$

Their methods of regulation and the modes of demand making that they engender lead me to link the process of decentralisation of supplies to the area of local politics, and at least tentatively suggest that it works against the process of democratisation. We therefore proceed to look at the various actors involved in concrete situations of negotiation, starting with the modes of demand making applied by users and others who seek to influence supplies as citizens residing in the community.

When individuals want to change their access to water within the new supply system, they use a range of strategies. They may step up individual supplies by digging deeper household wells or walking further to fetch water from the few remaining natural streams. Most strategies are, however, directed at influencing other agents of supply or regulation. I found cases where violence had been used, as when in the late 1990s one bore-hole owner was killed in an armed robbery commonly attributed to his profiting from water shortages at a time of drought. Another event that I documented was a conflict when consumers threatened to smash the equipment of the water vendors, when these had raised the price of water following the closing of a crucial tap connected to the public pipes running through the community. When the vendors organised a strike lasting several days, it was the leading ward head of the community that could muster the authority and legitimacy to step in as the mediator. In that instance, he arbitrated in favour of the vendors, with the acquiescence of the community, as further violence was prevented.

Users of water also form groups for collective action. The formation and activities of the self-help groups referred to above is one example that involves participatory management at the initiative of, and with support from, the local government. More pertinent as a regulating agent was Tudun Murtala Development Association (TUDA) which was at this time the most established town organisation. Originally formed by some young educated residents for the purpose of external lobbying, TUDA also works in support of community development and 'peace and harmony' internally.

Intervention in support of formal democratic procedures was also made by the local chapter of the Community Action for Popular Participation (CAPP). This was a branch of a national NGO with an agenda to mobilise members in the local community to challenge the agency of local government in the field of water. The main activity was to educate citizens to use the parliamentary process to its full potential. During 2000, the general focus of their city-wide campaign was on water, and in particular industrial pollution of water. Their mode of operation was public mobilisation and voters' education in the local elections, inducing people to take up water pollution as an election issue. Later, they organised meetings of groups of citizens, including those 
from Tudun Murtala, with local government officials, who were repeatedly interrogated concerning implementation of election promises between elections. ${ }^{11}$

But, more spontaneous interest group organising was rare, of limited success, unless played out in coalition with the neo-traditional rulers or with TUDA, which operated very close to the rulers. This was illustrated by the case of one experienced trade union organiser, a long-time resident in the community, and his frustrated attempts at gathering his neighbouring households in an independent protest. The issue of concern was the negative impact that newly drilled deep mechanical bore-holes in central parts of Tudun Murtala had on the water level in the local house wells. In his own interpretation of events, it was the fact that he did not ally with the neo-traditional community authorities that inhibited his neighbours from joining his campaign. ${ }^{12}$ Nevertheless, we did find the same man, also as the local organiser and trainer for this community, behind the explicit efforts of the above-mentioned CAPP to widen the arena for secular organisation. Together, his efforts show us the seed for a more secular form for organisation as part of a local politics of provision independent of neotraditional authorities. ${ }^{13}$

Notable for its absence is the influence of women as a group, and as individuals. For the majority of housewives in seclusion, the main managers of household-water, the development of the new water 'regime' that we have described here has meant a reversal to a neo-traditional dependence on their husbands for their access. Their previous control over supplies from public taps, that they exercised by sending younger girls to queue up to collect water, has been replaced by complete dependence on their husbands' duty to supply them from whatever source they choose. Usually this was done through sending water vendors to their door with their vans. The regulation of the conflicts in household relations that may then ensue is another area where neotraditional authorities have considerable influence. But, the housewives also enter the supplier trade in the capacity of vending cart owners. Non-Muslim female southerners may and do participate as entrepreneurs of distribution. And, even among those in seclusion, I met women who raised income from renting out water vending carts. The money earned was said to be used for instalments in the mutual saving societies, to which many women belong.

The parliamentary system offers vehicles for channelling grievances, by voting for and by approaching the Councillors for the wards, who were elected through a multi-party process. As representatives of the community, their field of influence also includes the regulation of appropriation and pollution of the available water by the competing industry, as well as matters of licensing and quality inspection handled by the local government, through the Council.

38 Also at the extra-community level the use of lobbying was at least as important as a mode of influencing provision and has typically involved delegations to the Water Board, to competing industries and to philanthropists. These delegations were found to include coalitions of representatives of the town association (TUDA), the self-help groups, and importantly and unavoidably a representative of the neo-traditional ward heads. A local government councillor, would sometimes also be included, particularly as, at this time, his origin was in the other groups (self-help and TUDA), which had recently formed the recruitment base for this function. This form for channelling grievances made the non-parliamentary forms for influence, including those of the neo-traditional rulers, important also in relations outside the community. 

field study, the neo-traditional ward head had a hand in very many of the modes of interest promotion and demand making taking place. Internally, in Tudun Murtala, we find him not only as a social advisor to individuals, but also as a mediator in conflicts between groups of citizens, e.g. in the case of the conflict of users vs. water vendors. Although elected (for life) by the residents, his inherited neo-traditional role as a keeper of 'peace and harmony' gave him particular authority in such situations. In external relations we rather find him as a co-ordinating lobbyist in coalitions of TUDA, self-help groups and even the local government council. He played this role in parties negotiating better terms with the industries as they competed for access to their water, and with the Water Board on the closure and mismanagement of communal water taps on the piped grid. We were also told of his role in alliance with neo-traditional district authorities in approaching philanthropists at the city level and negotiating shares in their ritual gifts of water. We can thus single him out as a very important regulator of relations with suppliers at spatial levels internal and external to the community.

However, he was not the only regulator. In the case of the self-help groups we have seen that their interventions are rather on the initiative of the local government. Negotiating with the community, their representatives, however, have to relate to the ward heads as brokers. The local government councillors have, of course, their own power base in the secular parliamentary system. But, there is considerable scope for neo-traditional authority meddling into the operation of this system through election rigging and lobbying for candidates, as was openly acknowledged by my ward head respondent. With decreasing municipal water supplies and with interventions from the local government being limited to the licensing of boreholes (said in 2007 to be increasingly evaded by drillers), and to highly intermittent health inspections, the regulating powers of the parliamentary representative were also becoming more and more marginal. Thus we do find co-operating and competing agents of regulation representing different social forces, and have to conclude that the local neo-traditional rulers are without doubt important holders of power. Indeed, the few attempts that have been made to organise outside of them, have been largely abortive, as in the case of the mobilisation of resistance to a deep bore hole by the resident unionist.

41 It is of interest to note (see Table 1) that the different scale-levels that are targeted have their distinct profiles with regard to agents and methods of demand-making and regulation. It seems that it is the role as conflict mediator between users and suppliers inside the community, which gives the neo-traditional ruler the particular powers that merit his inclusion as the formal head of the lobbying coalitions for external negotiations. We may add that these powers may have been enhanced by his role in mediating between interests of people in different parts of his ward. In an earlier phase, those residents in different locations in relation to the decreasing number of functioning taps on the grid represented such interest groups between which he was said to mediate. We can thus find matters of spatial contradiction also internal to the community.

The position of the neo-traditional authorities is further enhanced by their straddling different political realms. Above the ward-head in the traditional hierarchy is the district head, who has an office in the local government headquarters and who is appointed by the Emir of Kano. Access of the ward-head to these power holders will also facilitate his access to the Muslim philanthropists.

Bulletin de l'APAD, 31-32 | 2010 


\section{A Hybrid Governance Pattern and its Democratic Content} authority system of the Emir. They are allowed to exercise power by paternalistic means and are approached through clientilistic relations by individuals or collectives that submit to their authority. There is complete lack of transparency and accountability in their regulation of internal conflict. They are known to manipulate the electoral system of representation through illicit influence on nomination and voting. They have powers to lobby external regulators through direct contacts, individually as in contacts with the industry, and in combination with the other regulators. They do not encourage independent popular organisation around internal community interests, particularly not outside their own spheres of regulation. They certainly do not support the independent agency of women in provisioning relations outside the home.

47

It thus appears that in the context of Tudun Murtala, we can count three main forms of regulation combined in a hybrid mode of governance. The secular state (at various levels), the leaders of community organisations and the neo-traditional rulers are the regulators that combine to form one side of the community governance system. The legitimacy of each is based on the resident citizens who relate to them by more or less democratic means. Each regulator has their particular legitimacy base in the users and other citizens who are prepared to ally with them. These persons make up the other side of the mode of governance around water in this community.

The particular mode by which they each relate to users and other local residents can be scrutinized with regard to the democratic content of the relationship. Representation through the state and the electoral system is shown to be weak. Water issues are given very low attention in the election of ward councillors. Their influence on water provisioning issues in local government is also weak, and these issues are not given strong attention by them. Their representation of popular interests is also marred by the fact that elections of ward councillors are highly manipulated by neo-traditional rulers.

popular influence that is not well anchored in local traditions. Secular, non-traditional, forms for community action, as when initiated by a man with union experience and affiliation to a 'secular' NGO, was not met with great response. It was suggested that popular support was given only to organisations that were sanctioned by neotraditional rulers and which involved commitment to supporting their modes of regulation. This does not open for the practice of 'substantial' forms of democracy to any extent. The role of such forms in deepening the democratic deficit thus does not appear to be of immediate importance in this place context, with its particular historical and institutional set-up.

We may thus conclude that the degree of popular influence around water provisioning in Tudun Murtala cannot, on the basis of this material, be characterized as particularly democratic, neither by standards of electoral parliamentary democracy nor of direct 'substantial' democracy. One may even perceive of this mode of governance as a virtual reversal of the vision of democratisation of local governance of service provision that is commonly the aim of the policy discourse on the benefits of decentralised provision. 
But then this decentralisation is not really an intended one, but rather the location consequence of the process of liberalisation by default.

\section{Conclusions} sphere, based on a still viable Emir-centred authority structure, and its heritage as a centre for Islamic culture in a range of respects. It is also true that it is located in one of the Nigerian states (provinces) that have in the past decade (in 1999) introduced the shari'a criminal laws. The generally interesting circumstance is, however, the way in which these conditions have historically interacted in very particular ways with the locally and regionally specific forms of capitalist development that we see in this city (see e.g., Lubeck 1995 and Watts 1996). Probing the specific features of community level governance that this has yielded has served our main purpose, to demonstrate the relevance of considering the scale specific nature of the conditions of political organisation that influences popular access to livelihood resources when liberalisation has taken the form it has in this case. If we compare with conditions in cities in other parts of Africa or, even only in Southern Nigeria, where the neo-traditional powers have a different history of articulation with modern economic development, we are certain to find very distinct specificities in the ways they manifest themselves in provisioning politics at the community level. These are specificities that add to the characteristics of climate, hydrology, demography, economy and political culture in their historical and geographical contexts which explain the patterns that we find. The scope for comparative studies aiming for further generalisations is great in this field.

of course, the empirical study reported here could be expanded to confirm and deepen what we have seen so far. Some immediate questions concern first the actual relations between traditional rulers and residents which might also be differentiated in several categories. By what means do residents negotiate with the authority of regulation and influence? Who gains and who loses in the paternalistic system of contestation between them and informally and traditionally regulating agents ? In the short run, the close knowledge of conditions of poor residents held by the local neo-traditional power holders, together with their greater legitimacy as mediators between many locally based agents, may make them well equipped to represent their interests outside the community and to intervene internally in this conflict-prone and commonly riotexposed context. We must concede that our tools might need to be refined in order to catch this 'substantial' dimension of representation as well. Experiences from the neighbouring country of Niger, in the related Hausa society, where traditional authority is still formally recognized (and from where notably many water vendors in Tudun Murtala are said to be recruited), would be of interest to bring in for comparison. Further documentation might tie on to recent interesting research on the 
agents of regulation that develop in the 'twilight' zone between weak state institutions and other local authorities in places with differing conditions, as documented in the studies referred to above and reported in Lund (2006).

51 Conditions for forming collective organisations of shorter and longer duration, and the nature of their relations to neo-traditional authorities, are further themes for research. Points of departure originating from this study would include the close allegiance we noted of the town association (TUDA) to the neo-traditional authority, while modern secular organisations, such as CAPP and its related activists, have legitimacy problems. The historically low propensity for collective organisation may well be on its way to change. This may well happen under the influence of external NGOs, which sometimes have international funding connections as a basis for influence, as was the case with CAPP. It might be fruitful to look deeper into the occurrence of organisations in associated fields of service provision and material livelihood concerns. I saw in Tudun Murtala a number of community based organisations concerned with prevention of erosion along the central drainage canal running through the community. It is likely that their collective experience of organisation might have a spread effect. Connection with Islamic networks and their development is another phenomenon one might like to probe further.

52 While stressing the goals of satisfying human rights principles with respect to access to water, and recognizing the continued need for contestation among popular users and agents of influence over access, there is need to ask how the system can be made more respectful of popular interests in access and influence through a more democratic mode of provision. Responsibilities for furthering such goals will in some sense be spread over the social forces that participate in the game of water provisioning, both those on the regulating and on the demand-making sides. It would seem that public institutions at the city level, while of course circumscribed by national and provincial agents, are however in particular positions to act based on the comparative strength of their regulation powers.

53 Focusing on the public agents of regulation, our analysis in this case leads us to formulate a number of alternative policy options. They could strengthen the reach and presence of 'secular' democratic institutions of regulation at the community level, if this is where supply and regulation actually take place. They could further support forces of civil society organisation, to realize not only participatory management, but also political influence as part of the modes of provision. Finally, they could pay attention to the democratic problems associated with the remaining and possibly expanding powers of neo-traditional forces of regulation.

54 A challenging question to pursue is what difference a more decentralised state regulation structure, built on closer public presence at the community level, could make in this particular case. We certainly have no reason to romanticise the democratic qualities of the secular parliamentary system and its modes of regulating service and infrastructure provision in Nigerian cities. Still, after decades of oppressive military rule in Nigeria, elections to the local governments have been somehow revitalised, returning representatives from communities at the urban ward level to the secular parliamentary system of representation. Although these elections usually do not concern the concrete livelihood issues, that e.g., CAPP has tried to mobilise around and train citizens for, at least they do, with all their flaws and shortcomings, provide channels for popular demand-making on matters of urgent popular interest. 
In a different approach, one option is of course to return to the basic matter of the modes of liberalisation or commercialisation practised at the city level. The possibility might still be there to reverse the fragmented and informalised modes of provision and seriously consider the scope for overhauling the central, city level utilities of water processing and distribution. In case these utilities were state controlled, if not by ownership at least by effective regulation, and the task of supplying the whole city area with processed water were taken seriously, the potential to facilitate equalisation of access including the peripheral low income areas might still be there. Just as much in favour of this alternative may be the argument of the powerful economies of scale that are usually associated with provision through central purification plants and city wide pipe-systems of distribution. In a city like Kano, where comparatively abundant sources of water are available in the Kano River combined with conditions of a sensitive ground-water table, the option of expansion of supplies by deep bore-holes may compare very negatively with expansion by dependence on central intakes from Kano River. But, of course, in the final analysis it all boils down to the conditions set by the political economy of the particular place, as inserted in the national and global context.

\section{BIBLIOGRAPHIE}

Adama, O. 2007. Governing from Above. Solid Waste Management in Nigeria's New Capital City of Abuja. Stockholm: Stockholm Studies in Human Geography 17.

Andrae, G. 2007. Local Level Democratisation: CAPP and the traditionalisation of Water Provision in Tudun Murtala, Kano. Draft paper to CDR and CDRT conference on The Human Rights Movement in Nigeria. Kano 20-21 February 2007.

Andrae, G. 2005. Wanting Water : Popular Politics in Response to Changing Agency in a Peripheral Low-Income Area in Kano, Nigeria. In Space and Place in Development Geography (eds) A. Broekhuis, G. Nijenhuis \& G. Van Westen. Amsterdam : Rozenberg Publishers, Thela Thesis.

Andrae, G. \& B. Beckman 1985. The Wheat Trap : Bread and Underdevelopment in Nigeria. London. Zed Books.

Andrae, G. \& B. Beckman 1998. Union Power : Labour Regime and Adjustment in the Nigerian Textile Industry. Uppsala : The Nordic Africa Institute; Somerset, NJ : Transaction Publishers ; Kano : Centre for Research and Documentation.

Appelblad, J. 2008. Parting from the Privatisation Path ? Public Reform Strategies in the Ugandan Urban Water Sector. In The Provision and Politics of Public Services - Urban Governance in Uganda. Licentiate Thesis, Department of Human Geography, Stockholm University. Stockholm.

Belli, P. 1997. The Comparative Advantage of Government. Washington DC: World Bank.

Buur, L. \& H.M. Kyed 2006. Contested Sources of Authority: Reclaiming State sovereignty by Formalizing Traditional authority in Mozambique. Development and Change 37 (4) : 847-869.

Cadstedt, J. 2006. Influence and Invisibility : Tenants in Housing Provision in Mwanza City, Tanzania. Stockholm : Stockholm Studies in Human Geography 14. 
Cheema, G. S. 2005. Building Democratic Institutions : Governance Reform in Developing countries. Bloomfield, CT, USA: Kumarian Press, Inc.

Chikulo, B.C. 1998. Decentralisation and the Role of the State in the Future. In Governance and Human Development in Southern Africa (ed.) I. Mandaza. Harare : SAPES Books.

Cornwall, A. \& V. Schattan Coelho 2007. Spaces for Change : The politics of Citizen Participation in New Democratic Arenas. London : Zed Books.

Crook, R.C. \& J. Manor (eds) 1998. Democracy and Decentralisation in South Asia and West Africa : Participation, Accountability and Performance. Cambridge : Cambridge University Press.

Devas, N. (ed.) 2004. Urban Governance, Voice and Poverty in the Developing World. London : Earthscan.

Elander, I. 2002. Partnerships and Urban Governance. International Social Science Journal 172 (June) : 191-204.

Gaventa, J. 2006. Triumph, Deficit or Contestation ? Deepening the 'Deepening Democracy' Debate. IDS Working Paper 264. Brighton: Institute of Development Studies.

Gaventa, J. 2007. Foreword. In Spaces for Change : The politics of Citizen Participation in New Democratic Arenas A. Cornwall \& V. Schattan Coelho London : Zed Books.

Gboyega, A. 1998. Decentralisation and Local Autonomy in Nigeria's Federal System. Dept. of Political Science : Occasional Paper 49. Ibadan : University of Ibadan.

Hall, D., K. Bayliss \& E. Lobina 2002. Water privatisation in Africa. Paper presented at' Municipal Services Project Conference', Witwatersrand University : Johannesburg (May 2002). London : Public Services International Research Unit (PSIRU).

Hall, D., E. Lobina \& R. de la Motte 2005. Public Resistance to privatisation in water and energy. Development in Practice 15 (3-4), June 2005, 286-301.

Harriss, J., K. Stokke \& O. Törnqvist 2004. Politicising Democracy : The New Local Politics of Democratisation. Basingstoke : Palgrave Macmillan.

Kjellén, M. 2006. From Public Pipes to Private Hands : Water Provision in Dar es Salaam. Stockholm : Stockholm Studies in Human Geography 15.

Kjellén, M. \& G. McGranahan 2006. Informal Water Vendors and the Urban Poor. Human Settlements Discussion Paper Series Theme: Water-3. London, International Institute for Environment and Development (IIED) (http://www.iied.org/pubs/pdf/full/10529IIED.pdf)

Lund, C. 2006. Twilight Institutions: Public Authority and Local Politics in Africa. Development and Change 37 (4) : 685-705.

Lourenco-Lindell, I. 2002. Walking the Tight-Rope: Informal Livelihoods in a West African City. Stockholm : Stockholm Studies in Human Geography 9.

Mahwood, P. (ed.) 1993. Local Government in the Third World: The Experience of Decentralisation in Tropical Africa. Chicester, South : John Wiley and Sons.

Nilsson, D. 2006. Water for a Few : A History of Urban Water and Sanitation in East Africa. Licentiate dissertation, School of Architecture and the built environment, Royal Institute of Technology, KTH. Stockholm.

Oldfield, S. \& K. Stokke 2004. New Social Movements and Substantial Democratisation in South Africa. In Politicising Democracy : The New Local Politics of Democratisation (eds) J. Harriss, K. Stokke \& O. Törnquist. Basingstoke : Palgrave Macmillan. 
Solo, T.M. 1999. Small-scale entrepreneurs in the urban water and sanitation market. Environment and Urbanisation 11 (1) April, 117-132.

Törnquist, O. 2004. The Political Deficit of Substantial Democratisation. In Politicising Democracy : The New Local Politics of Democratisation (eds) J. Harriss, K. Stokke \& O. Törnquist. Basingstoke : Palgrave Macmillan.

UN 2006. Water : A shared responsibility. The UN World Water Development Report 2. New York: United Nations.

UNDP 2003. Human Development Report. The Millennium Development Goals. New York : United Nations Development Programme.

UNDP 2006. Human Development Report. Beyond Scarcity : Power, Poverty and the Global Water Crisis. Ch. 2 Water for Human consumption. New York : United Nations Development Programme.

UN Economic and Social Council 2003. Substantial Issues arising in the implementation of the International Covenant on Economic, Social and Cultural Rights. General Comment 15 (2002) The right to water. E/C. 12/2002/11 20 January 2003. New York.

WUP n.d. (late 1990s). Water Utility Partnership for Capacity Building in Africa. Strengthening the Capacity of Water Utilities to Deliver Water and Sanitation Services, Environmental Health and Hygiene to Low Income countries : Case Study for Kano (Town), Nigeria. Water Utilities Project 5. (as downloaded December 2007).

Watts, M. 1996. Islamic Modernities ? Citizenship, Civil Society and Islamism in a Nigerian City. Public Culture 8 (2), 251-289.

\section{NOTES}

1. This programme has received generous funding from the Swedish International Development Cooperation Agency (Sida) which is hereby acknowledged.

2. The form 'provision' is used in the general sense of the word while 'provisioning' is meant to emphasize a connotation of agency.

3. Regarding the earlier institutional context of water supplies for Kano see also WUP (n.d./late 1990s).

4. Documented on CD in Decentralisation in Practice: Power, Livelihoods and Cultural Meaning in West Africa, International Workshop Highlights, Uppsala, Sweden, May 4-6, 2004, International Institute for Environment and Development (IIED), London \& Dept. of Cultural Anthropology and Ethnology, Uppsala University, Uppsala (brochure + CD-ROM).

5. For the concept of governance applied in a service provisioning context in the global South see Devas (2004).

6. We may refer to all of them as 'users' for short.

7. Interviews Sabo Munkaila (2000 and 2002).

8. For a fuller account, see Andrae 2005.

9. Again, see Andrae 2005 for greater detail.

10. In analyzing this I refer to the time immediately after the replacement of a single ward with four different ones for this community. I perceived the old single office bearers to continue to be rather hegemonic in acting as representatives of the whole community.

11. Interview Yunuza Yau 2002, one time National President of CAPP. More detailed information on CAPP and its role in water provisioning is given in Andrae (2007).

12. But in 2007 we did hear of another, more successful neighbourhood protest on similar issues, where we do not, however, have information of the conditions of struggle. 


\section{RÉSUMÉS}

The case of water provisioning in Tudun Murtala, a peripheral low income area in Kano, Nigeria, is used to highlight an expanding form of decentralisation in infrastructure provision in African cities and the democratic problems associated with it. I look at the decentralisation 'by default' that is connected with the type of liberalisation that takes the form of informalisation of supplies. The concurrent separation of supply from state regulation means that the regulation of relations between suppliers and users escapes from public control at the municipal and local government level into traditional hands at the community level. For users, this entails a revived dependence on neo-traditional politics, rather than the development of the parliamentary system, as a mode of influencing the conditions of access to water provisioning.

Le cas de l'approvisionnement en eau de Tudun Murtala, une zone périphérique modeste de Kano, Nigeria, est utilisé pour analyser une forme émergente de décentralisation de l'approvisionnement en eau des villes africaines et les problèmes démocratiques associés à celleci. J'étudie la décentralisation "par défaut » qui est liée au type de libéralisation favorisant une informalisation de l'offre. La séparation de l'offre et du règlement de l'État, implique que la régulation des rapports entre fournisseurs et utilisateurs échappe au contrôle public communal et local pour aboutir au contrôle des institutions traditionnelles. Pour les utilisateurs, cet état des choses implique une dépendance ravivée de la politique néo-traditionnelle plutôt que le développement d'un système parlementaire, comme mode d'influence des conditions d'accès à l'eau.

\section{AUTEUR}

\section{GUNILLA ANDRAE}

Reader in Human Geography, Stockholm University : gunilla.andrae@humangeo.su.se 